\title{
PROTEIN ENRICHMENT OF SWEET POTATO RESIDUE WITH CO-CULTURE OF AMYLOLYTIC FUNGI BY SOLID- STATE FERMENTATION
}

\author{
SHANG-SHYNG YANG \\ Department of Agricultural Chemistry, Natwonal Tatu'an Uniterstty, Tatper. Taituan \\ 10617 , R.O.C.
}

Protein enrichment of sweet potato residue with amylolytic moulds by solid-state fermentation was higher than that obtained with amylolytic yeasts. The optimum initial moisture content for protein enrichment was $66 \%$ to 758 . Incrementally added nitrogen sources to the culture at zero time and at $24 \mathrm{~h}$ considerably improved the final protein content. During the cultivation, the moisture, ash and ATP contents increased, while the pH value decreased. A $1: 1$ co-culture of amylolytic mycelial fungi yielded a product with 32.4 o crude protein after 4 days incubation at $30^{\circ} \mathrm{C}$.

Key words: Protein enrichment, co-culture, amylolytic fungi, ATP content, solid-state fermentation.

\section{INTRODUCTION}

The protein demands for animal feeds and also for direct human consumption will inevitably increase during the next decade (11). In 1991 Taiwan imported $1.96 \times 10^{6}$ tons soybean from the U. S. A. at a cost of $4.93 \times 10^{8} \mathrm{U.S}$. Dollars (4). Consequently, the developments of local protein resources from renewable raw materials for animal feed is urgently required. The substrates traditionally used in solid state fermentations for the production of foodstuffs are rice, wheat, millet, barley, corn and soybeans. The use of agricultural wastes such as sweet potato residue, which intrinsically is not a good protein source for animal feed, might also be practicable because of its abundant supply, high 
productivity and reasonable cost in Taiman. Furthermore, siveet potato starch is readil $\because$ acnverted to biomass by man $y$ microorganisms capable of rapid growth $15,17,191$.

In order to be economicall $\because$ crifetitive, it must be possitele to perform the biocon:ersion of starchy materials into protein at rural level. Solid state fermentation facilitates tnis by reducing the cost of microbial cultivation, by improving the in wito rumen digestibility of substrate, and $b_{y}$ increasing the protein and fat contents of starchy or cellulosic materials'5,15,19J. In the previous paper'15), we found trat the amyiolytic ${ }^{\prime}$,asts could enrich the crude protein content of sweet potato residue from an initial ralue of 6 : up to 213 within 3 days by solid state fermentation. In this paper, the protein enrichment of sweet potato residue $b_{i}$ solid state fernentation with co-cuiture of amylolitic fungi was studied.

\section{MATERIALS AND METHODS}

\section{Sweet Potato Residue}

Sweet potato residue bas purchased ircm tre local narket in Taiman, ard scleened with a $\&$ to lo mesh to remore dust and large aggregates. It contained 14.0 to 16.1 molstule, 2.3 to 3.1 \& crude protein, 2.7 to $3.6 \%$ ash, 16.1 to $18.0 \%$ crude fibre, and 65.4 to $70.0 \frac{5}{5}$ cartohydrate $(15)$.

\section{Test Organisms}

Saccharomyces cererisiae $Y-187$ and $Y-191$ were provided by $C$. F. Lin llicrabial Resources Institute, Taiban;; S. Jiastaticus IFO 1046 and Saccharomyces sp. IFo 1426 were proyided by $W . H$. Wang t Research Institute for wines, Taiwan;: Schwanniomyces occidentalis $\mathrm{B} 53$ was provided $\mathrm{k} \% \mathrm{~J}$. C. du Freez I Deprartment of l.hicrobiology and Biochemistry, UDRS, South Africal: Candida lipolytica I Yarronia lipolytical. Aspergillus niger Tainan and Rhizopus sp. IHRRL-E88, IIRRL-695 and TER were obtained from our Department. All had amylolytic activities.

\section{Culture Hedia And Culture Conditions}

Amylolytic zeast were cultirated at $30^{\circ} \mathrm{C}$ or a slant of modified zeast malt extract nedium with soluble starch as carbon source151, while muld here cultivated at $30^{\circ} \mathrm{C}$ cr a slant of potato dextrose agar. The solid substrate comprisedigl sweet 
potato residue, 100; $\left(\mathrm{NH}_{4}\right)_{2} \mathrm{SO}_{4}, 1.25$; urea, $1.25 ;$ and $\mathrm{KH}_{2} \mathrm{PO}_{4}$. 1.0. The medium was mixed thoroughly with spores or cells and distilled water and incubated statically at $30^{\circ} \mathrm{C}$ for 4 days by mixing once a day in flask or a home-made column reactor $(19)$. The $\mathrm{pH}$ of the substrate was measured directly by immersing the electrode into the substrate, or determined after mixing an aliguot with 5 vol distilled water.

\section{Measurement of Adenosine Nucleotide}

After cultivation, mash was boiled with $0.02 \mathrm{MH} 7.6 \mathrm{Tr}$ is buffer for $10 \mathrm{~min}$. The filtrate was used for adenosine nucleotide measurement. Sample solution or adenosine nucleotide solution was mixed with luciferin-luciferase mixture, and the adenosine nucleotide was measured $\mathrm{D}^{\prime}$ ATP Photometer (Turner TD-20e Luminomer, USA,. ADP and AI.JP were converted to ATP with pyruvate kinase and adenylate kinase, respectively (8). Adenosine nucleotide was calculated from the standard curve of authenic compound.

Total Nitrogen, Soluble Nitrogen, Protein, Ash And Moisture Contents

Each sample was extracted with 5 vol distilied water by shaking far $20 \mathrm{~min}$, and soluble nitrogen in the extract was determined directly by the $k j \in l d a h l$ method $(6)$. The total nitrogen content of each sample, prior to extraction, was also determined. The crude protein content was calculated from the difference between the total nitrogen and soluble nitrogen contents, using the conversion factor of $6.25^{(16)}$. The ash content of samples was determined gravimetrically after 16 to $20 \mathrm{~h}$ at 550 to $600^{\circ} \mathrm{C}(13)$. The moisture content of the culture was determined by drying a sample at $60^{\circ} \mathrm{C}$ under vacuum for 8 to $12 \mathrm{~h}$ to constant mass $(15)$.

\section{RESULTS}

\section{Selection of Test Organism}

Protein enrichment of sweet potato residue with Rhizopus sp. NRRL-688, NRRL-695, TBR and $A$. niger Tainan ranged from 14.9 to 18.8 ; that with Schw. occidentalis $B 53$ and C. Iipolytica was from 9.6 to 10.3\%; and that with S. cerevisiae $Y-187$ and $Y-191$, S. diastaticus IFO 1046 and saccharomyces sp. IFO 1426 was from 5.0 to 7.5\%. In all experiments the moisture content of the substrate increased, whereas the $\mathrm{pH}$ values decreased. In the light 
of these results, Saccharomyces sp. IFO 1426, Schw. occidentalis B53, C. lipolytica, A. niger Tainan, and Rhizopus sp. NRRL-695 were selected for further study (Table 1 ).

\section{Initial Moisture Content}

Protein enrichment was affected by the initial moisture content which always increased during the cultivation. When Saccharomyces sp. IFO 1426 was inoculated into the solid medium with initial moisture content ranging from 55.9 to $79.6 \%$, the final moisture content increased by $0.5 \%$ up to $2.9 \%$ after 5 days. The protein content gradually increased with an increase in the initial moisture content but reached a maximum value at an initial moisture content of $66.8 \frac{8}{8}$ and at final moisture content of

Table 1. The protein and moisture contents and pH of sweet potato residue after the growth of different fungi in static solid state culture 1,2

\begin{tabular}{|c|c|c|c|c|c|c|}
\hline \multirow[t]{2}{*}{ Test strain } & \multicolumn{2}{|c|}{$\begin{array}{c}\text { [.loisture content } \\
\text { is }\end{array}$} & \multicolumn{2}{|l|}{$\mathrm{pH}$} & \multicolumn{2}{|c|}{$\begin{array}{c}\text { Protein content } \\
\left(\frac{2}{2}\right)\end{array}$} \\
\hline & Injてial & Final & Initial & Final & Initial & Final \\
\hline $\begin{array}{l}\text { Saccharomyces } \\
\text { sp. IFO } 1426\end{array}$ & 70.4 & 72.4 & 5.1 & 3.7 & 3.1 & 7.5 \\
\hline $\begin{array}{l}\text { S. diastaticus } \\
\text { IFO } 1046\end{array}$ & 69.7 & 72.8 & 5.5 & 3.6 & 3.2 & 7.3 \\
\hline S. cerevisiae $\mathrm{Y}-187$ & 69.0 & 72.0 & 4.8 & 4.4 & 3.2 & 5.0 \\
\hline S. cerevisiae $\mathrm{Y}-191$ & 72.8 & 74.0 & 4.6 & 3.7 & 3.2 & 5.6 \\
\hline $\begin{array}{l}\text { Schw. occidentalis } \\
\text { B53 }\end{array}$ & 69.0 & 76.7 & 5.2 & 3.0 & 3.4 & 10.3 \\
\hline C. lipolytica & 68.1 & 78.2 & 5.7 & 3.2 & 3.5 & 9.6 \\
\hline A. niger Tainan & 72.6 & 83.0 & 4.8 & 4.5 & 3.3 & 18.8 \\
\hline $\begin{array}{l}\text { Rhizopus sp. } \\
\text { NRRL-688 }\end{array}$ & 69.8 & 78.4 & 4.6 & 4.3 & 3.1 & 16.9 \\
\hline $\begin{array}{l}\text { Rhizopus sp. } \\
\text { NRRL-695 }\end{array}$ & 69.4 & 75.5 & 4.5 & 4.1 & 3.4 & 17.0 \\
\hline Rhizopus sp. TBR & 70.6 & 74.9 & 4.5 & 4.0 & 3.2 & 14.9 \\
\hline
\end{tabular}

1. All the data are the mean of experiments in triplicate.

2. Each gram of dry substrate inoculated with $10^{7}$ to $10^{8}$ spores or cells, supplemented with $1.25 \%\left(\mathrm{NH}_{4}\right)_{2} \mathrm{SO}_{4}$ and 1.258 urea as combined nitrogen sources and incubated at $30^{\circ} \mathrm{C}$ for 4 days. 
Table 2. The effect of the initial moisture content on the protein enrichment of sweet potato residue in flask culture at $30^{\circ} \mathrm{C}$ for 5 days

\begin{tabular}{|c|c|c|c|c|c|c|}
\hline \multirow[t]{2}{*}{ Test strain } & \multicolumn{2}{|c|}{$\begin{array}{l}\text { Moisture content } \\
\left(\frac{q}{8}\right)\end{array}$} & \multicolumn{2}{|c|}{$\mathrm{pH}$} & \multicolumn{2}{|c|}{$\begin{array}{c}\text { Protein content } \\
\qquad\left(\frac{8}{8}\right)\end{array}$} \\
\hline & Initial & Final & Initial & Final & Initial & Final \\
\hline accharomyces & 55.9 & 56.4 & 4.8 & 4.3 & 3.2 & 4.0 \\
\hline p. IFO 1426 & 59.2 & 60.9 & 4.6 & 3.8 & 3.2 & 5.6 \\
\hline & 66.8 & 69.7 & 4.5 & 3.8 & 3.2 & 8.4 \\
\hline & 71.3 & 73.1 & 4.9 & 3.8 & 3.2 & 7.6 \\
\hline & 75.2 & 77.6 & 4.9 & 4.0 & 3.2 & 7.2 \\
\hline & 79.6 & 82.2 & 4.7 & 4.0 & 3.2 & 7.1 \\
\hline Rhizopus sp. & 55.5 & 58.4 & 5.1 & 4.8 & 3.8 & 17.8 \\
\hline NRRL-695 & 59.6 & 63.6 & 5.2 & 4.4 & 3.6 & 17.8 \\
\hline & 65.3 & 68.6 & 5.1 & 4.2 & 3.8 & 18.0 \\
\hline & 68.8 & 74.2 & 5.1 & 4.5 & 3.8 & 18.5 \\
\hline & 75.6 & 78.2 & 5.1 & 4.6 & 3.3 & 18.6 \\
\hline & 80.3 & 83.7 & 5.1 & 4.6 & 3.4 & 18.6 \\
\hline
\end{tabular}

1. All the data are the mean of experiments in triplicate.

2. The inoculum size was $10^{7}$ to $10^{8}$ spores or cells per gram of dry substrate.

69.7\%. In all cases the substrate $\mathrm{pH}$ decreased markedly. While Rhizopus sp. NRRL-695 was used with initial moisture content ranging from 55.5 to $80.3 \%$, the protein content also gradually increased with an increase in the initial moisture and reached a plateau at an initial moisture content of $68.8 \%$. The substrate $\mathrm{pH}$ decreased during the cultivation. The optimum initial moisture content appeared to be in the region of 65 to 75 옹 (Table 2).

\section{Nitrogen Supplementation}

To improve the efficiency of utilization of the nitrogen source, a mixture of ammonium sulphate and urea (at a $1: 1$ ratio) was added to the substrate with $1.25 \%$ dry weight of each at zero time and again at $24 \mathrm{~h}$ instead of just $2.5 \%$ of each nitrogen source addition at zero time. The addition of the nitrogen sources in two increments greatly enhanced the degree of protein enrichment resulting in a final protein content of 17.0 to $29.4 \%$, while the nitrogen sources had only been added at the start of the cultiva- 
tion having in a final protein content of 8.6 to $18.2 \%$. The highest protein contents $(29.4 \%$ and $26.1 \%)$ were obtained with the moulds Rhizopus sp. NRRL-695 and $A$. niger Tainan, whereas the maximum protein contents obtained with Schw. occidentalis B53, C. lipolytica, and Saccharomyces sp. Ifo 1426 was only 18.2\%, $17.2 \%$. and $17.0 \%$, respectivel $\%$.

\section{Column Reactor}

Protein enrichment in a column reactor with Saccharomyces sp. IFO 1426 and $A$. niger Tainan is shown in Table 3. The moisture content increased by 0.8 to $3.6 \%$, and by 8.1 to $9.7 \%$ over 4 days with Saccharomyces sp. IFO 1426 and $A$. niger Tainan, respectivel $i$. The $\mathrm{pH}$ values decreased from the initial values of 4.3 to 4.4 to final values in the range of $\mathrm{pH} 3.1$ to 3.8 . The Saccharomyces strain gave a final protein content of 7.9 to 8.98 , whereas the value obtained with $A$. niger was 18.1 to $18.8 \%$. Protein enIichment with nitrogen supplementation after $24 \mathrm{~h}$ incubation in column reactor clearly showed that the additional supply of nitrogen greatly enhanced microbial growth and protein content. The Saccharomyces strain gave a final protein content of $17.5 \frac{8}{6}$ with nitrogen supplementation, whereas the value obtained with Schw. occidentalis 853 was $17.8 \%$ (Table 4 ). These results were also very consistent with the protein enrichment in the flask

Tabie 3. The change in moisture and protein contents and pH in a column reactor with different initial moisture content at $30^{\circ} \mathrm{C}$ for 4 days 1

\begin{tabular}{|c|c|c|c|c|c|c|}
\hline \multirow[t]{2}{*}{ Test strain } & \multicolumn{2}{|c|}{ 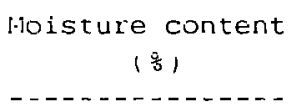 } & \multicolumn{2}{|c|}{$\mathrm{pH}$} & \multicolumn{2}{|c|}{$\begin{array}{c}\text { Protein content } \\
\left(\begin{array}{l}\left(\frac{y}{8}\right)\end{array}\right.\end{array}$} \\
\hline & Initial & Final & Initial & Final & Initial & Final \\
\hline Saccharomyces sp. & 64.3 & 67.9 & 4.3 & 3.8 & 3.2 & 8.6 \\
\hline IFO 1426 & 70.5 & 72.9 & 4.3 & 3.8 & 3.2 & 7.9 \\
\hline & 72.4 & 74.4 & 4.4 & 3.7 & 3.2 & 8.5 \\
\hline & 75.0 & 75.8 & 4.3 & 3.2 & 3.2 & 8.9 \\
\hline A. niger Tainan & 65.4 & 74.3 & 4.3 & 3.5 & 3.3 & 18.1 \\
\hline & 70.2 & 80.0 & 4.4 & 3.1 & 2.9 & 18.7 \\
\hline & 72.3 & 82.0 & 4.4 & 3.2 & 3.0 & 18.8 \\
\hline & .5 .0 & 83.1 & 4.4 & 3.2 & 2.8 & 18.6 \\
\hline
\end{tabular}

1. Culture conditions were same as Table 1 described. 
Table 4. Protein enrichment of sweet potato residue with mono- and co-culturesof different fungi in a solid state cultivation at $30^{\circ} \mathrm{C}$ with nitrogen supplementationat $24 \mathrm{~h} /$

\begin{tabular}{|c|c|c|c|c|c|c|c|c|c|}
\hline Test organism & $\begin{array}{l}\text { Culture } \\
\text { neriod } \\
\text { (day) }\end{array}$ & $\begin{array}{l}\text { Moisture } \\
\text { content } \\
\text { (q) }\end{array}$ & $\mathrm{pH}$ & $\begin{array}{l}\text { Ash } \\
\text { (x) }\end{array}$ & $\begin{array}{c}\text { AMP } \\
(\mathrm{nM} / \mathrm{g})\end{array}$ & $\begin{array}{l}\mathrm{ADP} \\
(\mathrm{nM} / \mathrm{g})\end{array}$ & $\underset{(n M / g)}{A I P}$ & $\begin{array}{l}\text { Energycharge } \\
\text { ATP+1/2ADP } \\
\text { AMP+ADP+AIP }\end{array}$ & $\begin{array}{l}\text { Protein } \\
\text { content } \\
(\%)\end{array}$ \\
\hline \multicolumn{10}{|l|}{ (A) FLASK CUL IURE } \\
\hline Saccharonyces sp. & 0 & 64.1 & 5.5 & 4.6 & 5.7 & 2.4 & 1.0 & 0.24 & 3.6 \\
\hline \multirow[t]{2}{*}{ IFI 1426} & 2 & 64.2 & D. 0 & 4.8 & 27.1 & 16.1 & 11.7 & $0.30^{\circ}$ & 12.0 \\
\hline & 4 & 67.8 & 5.7 & 5.7 & 38.6 & 31.6 & 23.8 & 0.42 & 17.0 \\
\hline Schwanni omyces & $\mathbf{0}$ & 04.2 & 4.7 & - & - & - & 0.1 & - & 3.3 \\
\hline \multirow[t]{2}{*}{ occidentalis 853} & 2 & 68.6 & 3.6 & - & - & - & 40.3 & - & 12.6 \\
\hline & 4 & 68.4 & 3.7 & - & - & - & 26.7 & - & 18.2 \\
\hline \multirow[t]{3}{*}{ Candida lipolytica } & 0 & 64.3 & 4.4 & - & - & - & 0.1 & - & 4.1 \\
\hline & 2 & 65.1 & 6.8 & - & - & - & 2.3 & - & 11.5 \\
\hline & 4 & 67.0 & 7.4 & - & - & - & 8.3 & - & 17.2 \\
\hline \multirow[t]{3}{*}{ Aspergillus niger lainan } & an 10 & 63.4 & 5.4 & 4.2 & 5.0 & 2.7 & 1.1 & 0.28 & 3.7 \\
\hline & 2 & 73.8 & 3.3 & 6.9 & 94.2 & 32.4 & 24.4 & 0.27 & 17.1 \\
\hline & 4 & 77.1 & 6.4 & 8.8 & 353.1 & 179.3 & 35.7 & 0.22 & 29.4 \\
\hline \multirow[t]{3}{*}{ Rhi zopus Sp. NRRI-695 } & ù & 64.4 & 5.5 & 4.6 & 5.3 & 2.9 & 0.8 & 0.25 & 3.4 \\
\hline & 2 & 72.5 & 4.8 & 6.8 & 596.4 & 278.5 & 45.7 & 0.20 & 16.6 \\
\hline & 4 & 75.5 & 8.3 & 7.2 & 317.2 & 260.7 & 70.2 & 0.31 & 26.1 \\
\hline \multicolumn{10}{|l|}{ (B) COLUMN REACTOR } \\
\hline Saccharomyces sp. & 0 & 63.3 & 5.1 & 4.3 & - & - & 0.3 & - & 4.3 \\
\hline \multirow{2}{*}{ IFO 1426} & 2 & 65.2 & 4.9 & 4.8 & - & - & 0.4 & - & 11.7 \\
\hline & 4 & 08.8 & 5.0 & 5.5 & - & - & 17.6 & - & 17.5 \\
\hline Schwanniomyces & ) & 63.8 & 4.8 & 4.6 & - & - & 0.4 & - & 4.6 \\
\hline \multirow[t]{2}{*}{ occidentalis 853} & 2 & 68.5 & 4.5 & 5.5 & - & - & 29.0 & - & 12.1 \\
\hline & 4 & 71.3 & 4.4 & 6.0 & - & - & 27.9 & - & 17.8 \\
\hline Saccharonyces SP. IFD & 0 & 64.5 & 5.5 & 4.4 & 5.4 & 2.8 & 1.1 & 0.27 & 3.6 \\
\hline \multirow{2}{*}{1426 and C.lipolytica } & 2 & 65.5 & 5.9 & 4.9 & 62.2 & 32.7 & 14.8 & 0.28 & 12.8 \\
\hline & 4 & 65.6 & 7.6 & 4.6 & 182.9 & 158.9 & 36.8 & 0.31 & 18.8 \\
\hline Schw. occidentalis 8.53 & 0 & 03.8 & 4.5 & - & - & - & ט̄. 1 & - & 4.1 \\
\hline \multirow[t]{2}{*}{ and C. lipolytica } & 2 & 69.2 & 5.1 & - & - & - & 22.5 & - & 12.5 \\
\hline & 4 & 71.3 & 5.3 & - & - & - & 15.7 & - & 18.6 \\
\hline Saccharomyces sp. IF0 & 0̈ & 64.5 & 5.5 & 4.6 & 5.2 & 2.9 & 0.9 & 0.26 & 3.5 \\
\hline 1426 and Rhizopus sp. & 2 & 69.8 & 4.3 & 5.9 & 236.2 & 246.0 & 21.0 & 0.29 & 16.2 \\
\hline NRRL -695 & 4 & 72.7 & 4.2 & 6.4 & 308.6 & 214.2 & 23.2 & 0.24 & 25.9 \\
\hline Schw. occidental is B53 & 0 & 04.1 & 4.7 & - & - & - & 0.1 & - & 4.1 \\
\hline and Rhizopus ST. NRRL- & 2 & .3 .4 & 4.6 & - & - & - & 28.3 & - & 14.4 \\
\hline 695 & 4 & .6 .8 & 8.5 & - & - & - & 19.5 & - & 26.2 \\
\hline C. Lipolytica and & 0 & 64.9 & 5.3 & $4 . \overline{8}$ & 5.3 & 3.2 & 1.0 & 0.27 & 3.6 \\
\hline \multirow[t]{2}{*}{ Rhizopus sp. NRRL-695 } & 2 & 70.9 & 4.5 & 6.4 & 735.4 & 236.1 & 36.8 & 0.15 & 12.7 \\
\hline & 4 & 76.1 & 8.1 & 8.2 & 301.7 & 213.7 & 10.1 & 0.27 & 26.7 \\
\hline A. niger Tainan and & 0 & 64.1 & 5.4 & 4.5 & 5.5 & 2.6 & 0.7 & 0.23 & 3.6 \\
\hline Rhizopus sp. NRRL -695 & 2 & 73.5 & 4.6 & 6.9 & 731.6 & 256.8 & 47.6 & 0.17 & 15.7 \\
\hline & 4 & 78.5 & 6.8 & 8.3 & 395.2 & 241.4 & 54.0 & 0.25 & 32.4 \\
\hline Blank & 0 & 64.2 & 4.6 & 4.6 & 5.0 & 2.4 & 0.7 & 0.23 & 3.4 \\
\hline & 2 & 64.5 & 4.4 & 4.7 & 4.4 & 2.1 & 0.6 & 0.23 & 3.3 \\
\hline & 4 & 64.0 & 4.7 & 4.6 & 4.2 & 2.2 & 0.4 & 0.23 & 3.4 \\
\hline
\end{tabular}

1. The culture conditions were as in Jable 3 , but with supplementation with $\left(\mathrm{NH}_{1}\right)_{2} \mathrm{SO}_{4} \quad 1.25 \%$ and uree $1.25 \%$ at $24 \mathrm{~h}$. 
culture.

\section{Co-culture of Amylolytic Fungi}

Protein enrichment of sweet potato residue with mono-culture or with a $1: 1$ co-culture of amylolytic fungi (by the number of spores or cells, at $30^{\circ} \mathrm{C}$ for 4 days is shown in Table 4 . Moisture content of the final products with the mono-culture of amylolytic moulds was higher than that with amylolytic yeasts; while in the case of co-culture of amylolytic moulds and amylolytic yeasts, moisture content of the final products was the same as that of mono-culture of amylolytic moulds. During the incubation, the substrate $\mathrm{pH}$ of co-culture of amylolytic fungi also decreased initially then increased later. The mono-culture of Rhizopus sp. NRRL-695 and $A$. niger Tainan had the products with 26.1 to $29.4 \%$ of protein for 4 days cultivation, while c. Iipolytica. Saccharomyces sp. Ifo 1426 and Schw. occidentalis B53 had the products with 17.0 to 13.2 응 of protein. Co-culture of these two amylolytic fungi had the products with $32.4 \%$ of protein. Protein enrichment of co-culture of amilolytic yeasts was the same as that of mono-culture and the same phenomena was found in the coculture of amyiolytic moulds. In the case of the co-culture of amylolytic yeasts and amylolytic moulds, protein content in the final product was intermediate between the values of the monocultures.

ATp And Ash Contents In The Solid liedium

To investigate the biomass content in the solid substrate, the ATP content was measured and is snown in Table 4. During the cultivation, ATP content increased. Rhizopus sp. NRRL-695 had the highest ATP content in the nedium, then the co-culture of amylolytic moulds and the mono-culture of $A$. niger Tainan. While $C$. lipolytica was the least. The energy charge also increased with time. Saccharomyces sp. Ifo 1426 had the highest value, while $A$. niger Tainan had the least.

Ash content increased during incubation, A. niger Tainan had the highest value, then the co-culture of $A$. niger Tainan and Rhizopus sp. NRRL-695, and Saccharomyces sp. IFO 1426 had the lowest. The final protein content of products of the mono-culture of amylolytic moulds, and the co-culture of amylolytic mould and amylolytic yeast was between 25.9 and $29.4 \%$, and the final protein content of the mono-culture of amylolytic yeasts and the coculture of amylolytic yeasts was between 17.0 and 18.8 . 
In 1991 Taiwan cultivated 12,819 ha of sweet potato with the annual production 224,272 tons. The productivity was 1.75 ton/ha (4). Sweet potato residue contains $2.3 \%$ protein and $65.4 \%$ total carbohydrate and is, in itself, not a good resource of protein for animal feeding. However, it could be enriched with protein by using amylolytic furigl $b_{y}$ a solid state fermentation process $(11$, 151. In a previous paper. we found that amylolytic yeasts enrlohed the protein of sweet putato residue from the initial protein $6 \%$ to the final protein $21 \%$ for 2 to 3 days incubation (15). In this paper, it was found that amylolytic moulds had a higher potential than the amilolytic yeasts.

During the fermentation, the moisture content of substrate increased. The increase might be due to the producition of riatabulic water of fungl, or the release of water in oxidation of carbohydrate, as had been observed in the spawn of mushroom (14). protein enrichment of sugar beet pulp(3,18), and antibiotics production of sweet potato residue(19). Microbial utilization of the ammonium sulfate as the nitrogen source can cause the pH decrease $(2)$. When nitrate or urea serves as nitrogen sources, the $\mathrm{pH}$ value rose due to the reduction of nitrate to $\mathrm{R}_{-} \mathrm{NH}_{3}{ }^{+}$or urea decomposition( 9 ). During the fermentation, the $\mathrm{pH}^{3}$ initially decreased, but subsequently increased. pH control in solid substrate may be obtalned by using different ratios of ammonium salts and urea (15), ammonium ritrate or sodium nitrate(17), or a buffering agent such as $\mathrm{CaCO}_{3}(10)$.

In order to enrich the protein content from 3-68 to 20-30\%, an addition of 48 nitrogen supplementation is necessary theoretically. In this study, we found that the fractional supplementation of nitrogen could result in a higher protein enrichment than supplementation added only at zero time.

ATP is a potentral index of microbial biomass ( 7$)$, and energy charge is a useful indicator of the energetic state of cells $(12)$. ATP content increased during the cultivation. ADP and AMP contents also increased as incubation proceeded except for the mono-culture of Rhizopus and the co-culture of amylolytic fungi and Rhizopus. Energy charge of the mono-culture or the co-culture of amylolytic fungl was petween 0.15 and 0.42 . The value of energy charge was lower than that of yeast cells growing anaerobically before early stationary phase or yeast cells growing aerobically during log phase and stationary phase(1). The low value of energy charge in solid state fermentation might be due to the low concentration of oxygen or glucose in the 
substrate. The oxigen conicentation in tre solid substrate was orily 5z and $3 z$ at $24 h$ anj $43 r_{1}$ incubation. respectively. Ball and Atkinson also lndicated that the energy charge was 0.14 to 0.40 in anaerobic condition ard long-term starvation'l'. Since the microbes ard substrate were static in solid state fermentation, therefore the nutrient supply might be also a limiting factor for low value of energy charge.

The use of the filamentous fungi proved to be much better at enriching the protein conterit of the sweet potato residue than the yeasts. This was probably malniy because the moulds, trirough growth of their hiphae. were better able to penetrate and spread through the solid substrate. The use of co-cultures of the moulds, yeasts, or a mould uth a jeast falled to enhance the protein enrichment. A column resctor gave results comparable to those obtained in static fiask cultures.

\section{ACKNOWLEDGEMENT}

The author tharks Profissjr Janies $C$. du freez of University of the orange free state. Bloemfortein. South ffrica for his helpful comments, arid cre iational science council of tre Republic of China for flnaicial support INSC ?9-0409-B002-52 and NSC $80-0109-8002-27$.

\section{REFERENCES}

1. W. J. Ball Jr. ard D. E. Arkirison, Adenylate energy charge ir Saccharomyces cerevisiae during starvation. J. Bacteriol.. 121. $975-982$.

2. C. L, Cooney, Growth of microorganisms, in Biotechnology, H. J. Renm and G. Feed (Eds), 'erlag Chemle, welrheim, Vol. 1, 7311211981 !

3. A. Durand and D. Chereal. A new pilot reactor for solid-state fermentation: appicaticin to tre protein enrichment of sugar beet pulp. Blotechnol. Bloeng. 31. t-j-486119831.

4. Econiules and Elarilid [efartmert. Custom statistics-1991

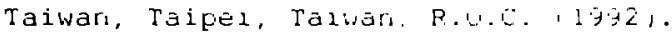

5. G. A. Grant, Y. H. Han and A. W. Anderson, Pilot-scale semisolid fermentation of strau, Afpl. Enuzron. Hicrobiol., 35. 549553 (1978).

6. W. Horwitz, Cereal food, in offlclal Methods of Analysis of the Association of officlal Analytical Chemists, 13 th ed. p. 211 (1980).

7. D. H. Karl, D. R. Jones, J. A. Noritsky, C. D. Winn and P. 
Bossard, Specific growth rates of natural microbial communities measured by adenine nucleotide pool turnover, J. Microbiol. Methods, 6. 221-235 (1987).

8. A. Lundin and A. Thore, Comparison of methods for extraction of bacterial adenine nucleotides determaned by firefly assay. Appl. Microbiol., 5. 713-721 (1975).

9. D. A. Mitchell, H. W. Doelle and P. F. Greenfield, Agar plate growth studies of Rhizopus oligosporus and Aspergillus oryzae to determine their sustability for solid state fermentation. Appl. Microbiol. Eiotechnol., 28. 595-602 (1988).

10. I. D. Reid, Solid state fermentations for biological delignification, Enzyme Microblol. Technol., 11. 786-803 (1989).

11. J. C. Senez, M. Raimbault ard F. Deschamps, Protein enrichment of starchy substrate for animal feeds by solid state fermentation, World Anım. Fey. 35. 36-39 (1980).

12. E. Sivori, Adenylic nusleotides and energy charge during the embryonic development of Bufo arenarum, Comp. Biochem. Physiol., 85B. 573-576 (1986).

13. The AVI Publishing Company Inc, Food Analysis Laboratory Mannual, West Port, Connecticut, 85-86, and 102 (1975).

14. H. H. Wang, Water absorption characteristics of cellulosic wastes and solid state fermentation, Proc. 2nd World Congr. Chem. Eng., 297-300 (1981).

15. S. S. Yang, Protein enrichment of sweet potato residue with am $y$ lolytic $y$ easts by solid state fermentation, Biotechnol. Bioeng., 32. $880-890,19881$.

16. S. S. Yang, S. L. Char.g, C. B. Wei and H. C. Lin, Reduction of waste production in the KJeldahl method, J. Biomass Energy Soc. China, 10. 147-155 (1991).

17. S. S. Yang and W. F. Cniu. Procease production with sweet potato residue by solid state fermentation. Chin. J. Microbiol. Immunol., 19. 276-288 (1986).

18. S. S. Yang, A. Durand and H. Blachere, Protein enrichment of sugar beet residue with conidia of Trichoderma album by solid state fermentation, Chin. J. Microbiol. Immunol., 19. 11-22 $(1986)$.

19. S. S. Yang and S. S. Yuan, Oxytetracycline production by Streptomyces rimosus in solid state fermentation of sweet potato residue, world J. Microbial. Biotechnol., 6. 236-244 (1990). 